\title{
Daya Tarik Wisata yang ada di Kecamatan Senapelan Kota Pekanbaru
}

\author{
ELWIRA HANDAYANI \\ Sekolah Tinggi Pariwisata Riau \\ Jl. Pattimura No. 54, Cinta Raja, Sail, Cinta Raja, Kec. Sail, Kota Pekanbaru, Riau 28127 \\ E-mail : elwirahandayani@gmail.com
}

\begin{abstract}
Senapelan District is the forerunner of Pekanbaru City that has a lot of tourist attraction, especially in culture and history. It was supported also by the tourist attractions and tourism components. Additionally on RPJMD Pekanbaru City Year 2012-2017, this district will be used as recreational area and cultural heritage. Diversity of tourist attractions are offered, but that's not integrated with each other, so that need for the concept of integration in the management of the District of Senapelan so that the potential of tourism can thrive. The research using qualitative descriptive analysis using in-deep interviews to explore the components in the development of tourist destinations in District Senapelan.
\end{abstract}

Keywords: Potency, Region, Integrated, Senapelan

Pariwisata memegang peranan penting dalam pembangunan ekonomi, hal ini tidak saja berlaku dinegara-negara maju, tetapi juga dinegara-negara berkembang dimana sektor pariwisata dapat dijadikan alat dalam meningkatkan kualitas hidup masyarakat, khususnya masyarakat disekitar objek wisata. Melalui aktivitas pariwisata yang terjadi di suatu destinasi, diharapkan kelestarian lingkungan dapat terjaga. Hal ini sejalan dengan pendapat Harrington (2001:1) "Tourism industry contributes considerably to the society, economy, and to the environment - either man made or natural". Industri pariwisata memberikan kontribusi cukup kepada masyarakat, pada ekonomi dan lingkungan, baik buatan manusia ataupun alami.

Syarifuddin (2013) mengatakan bahwa Provinsi Riau merupakan salah satu propinsi yang memiliki potensi wisata yang sangat besar. Meskipun kondisi alam di Riau terbatas dan berbeda dengan daerah lainnya yang memiliki gunung, tapi Riau memiliki 290 daya tarik wisata. Selain itu event tahunan yang diselenggarakan setiap kabupaten yang ada di Riau juga merupakan industri pariwisata yang cukup berpotensi. Meskipun demikian, ketersediaan infrastruktur dan fasilitas di
Provinsi Riau ini masih menjadi kendala utama dalam pengembangan industri pariwisatanya seperti jalan menuju objek wisata yang rusak, transportasi, penginapan yang kurang dan fasilitas pendukung lainnya. Hal inilah yang menjadi pekerjaan rumah terbesar bagi pemerintah provinsi dan pemerintah pusat. (wisatapekanbaru.com)

Pekanbaru merupakan ibu kota Provinsi Riau dengan luas sekitar 632.26 $\mathrm{km} 2$ dan secara astronomis terletak di antara $0^{\circ} 25^{\prime}-0^{\circ} 45^{\prime}$ Lintang Utara dan $101^{\circ} 14^{\prime}-101^{\circ} 34^{\prime}$ Bujur Timur. Dengan batas wilayah di bagian utara Pekanbaru dengan Kabupaten Siak, di bagian timur dengan Kabupaten Siak dan Kabupaten Pelalawan, di bagian selatan dengan Kabupaten Pelalawan dan Kabupaten Kampar, sedangkan di bagian barat dengan Kabupaten Kampar.

Secara administrasi pemerintahan Kota Pekanbaru dikepalai oleh Walikota, yang berdasarkan Peraturan Daerah Nomor 3 Tahun 2003 dimekarkan dari 8 wilayah administrasi kecamatan menjadi 12 wilayah administrasi kecamatan. Wilayah administrasi kecamatan selanjutnya terbagi lagi menjadi kelurahan, yang berdasarkan Peraturan 
Daerah Nomor 4 Tahun 2003, dimekarkan dari 50 wilayah administrasi kelurahan menjadi 58 wilayah administrasi kelurahan. Wilayah administrasi kelurahan terbagi lagi menjadi 539 Rukun Warga (RW) dan 2.266 RT (Rukun Tetangga). Populasi penduduk Kota Pekanbaru sampai dengan Tahun 2004 menurut Dinas Pendaftaran Penduduk Kota Pekanbaru mencapai 711.130 jiwa, dengan demikian tingkat kepadatan penduduk Kota Pekanbaru lebih kurang 1.125 jiwa/km2. (bappeda.pekanbaru.go.id).

Mulai diberlakunya otonomi daerah oleh pemerintah pusat pada awal tahun 2001, membuat pemerintah Kota Pekanbaru semakin gencar dalam melakukan pembangunan diberbagai sektor, termasuk sektor pariwisata.

Pekanbaru dulunya hanyalah merupakan sebuah dusun kecil yang dipimpin oleh seorang batin (kepala dusun) yang dalam perkembangannya berpindah ke dusun baru yang dikenal dengan Dusun Payung Sekaki yang terletak dipinggiran Sungai Siak. Seiring berjalannya waktu, pada hari Selasa tanggal 21 Rajab $1204 \mathrm{H}$ atau tanggal 23 Juni 1784 M., berdasarkan musyawarah datuk-datuk empat suku (Pesisir, Lima Puluh, Tanah Datar dan Kampar), negeri Senapelan diganti namanya menjadi Pekan Baharu. Sejak saat itu, setiap tanggal 23 Juni ditetapkan sebagai hari jadi Kota Pekanbaru. Mulai saat itu pula, sebutan Senapelan sudah ditinggalkan dan mulai populer dengan sebutan Pekan Baharu. Sejalan dengan perkembangannya, kini Pekan Baharu lebih populer disebut dengan sebutan Kota Pekanbaru, dan oleh pemerintah daerah ditetapkan sebagai ibu kota Provinsi Riau.

Perkembangan Kota Pekanbaru saat ini cukup luar biasa. Begitu juga dengan perkembangan ekonomi dan pariwisatanya. Apalagi di Riau telah diselenggarakan ajang Pekan Olahraga Nasional ke XVIII 2012. Banyak investor yang membangun hotel berbintang yang tentunya bukanlah bisnis musiman, namun merupakan bisnis yang permanen sehingga layak untuk dikembangkan sebagai wisata belanja dan MICE. (wisatapekanbaru.com,2013).

Kota Pekanbaru sebagai salah satu destinasi wisata di Indonesia memiliki peluang untuk berkembang menjadi daerah tujuan wisata. Hal ini didasarkan atas data kunjungan wisatawan mancanegara menurut pintu masuk bandara terlihat siklus peningkatan kunjungan wisatawan di musim liburan.

Peningkatan kunjungan wisatawan terbanyak ke Pekanbaru menurut pintu masuk yaitu Bandara Sultan Syarif Kasim II yaitu pada bulan November yaitu mencapai 3.559 orang dan pada bulan Desember yaitu 3.404. Dengan kunjungan terendah yaitu pada bulan Juli yaitu 1.713 orang.

Kota Pekanbaru merupakan kota perdagangan dan jasa terbukti dari mulai menjamurnya pertokoan, hotel, mall dan perkantoran di kota ini dengan pendapatan terbesarnya adalah dari sektor pajak dan hasil bumi berupa minyak bumi dan kelapa sawit. Walaupun dikenal sebagai kota bisnis, Pekanbaru tidak berbeda dengan kota-kota lainnya di Indonesia yang memiliki banyak objek wisata baik alam, sejarah, budaya, maupun buatan.

Kecamatan Senapelan merupakan salah satu kecamatan yang ada di Kota Pekanbaru. Bila dilihat dari segi lokasi dan dari banyaknya objek wisata, Kecamatan Senapelan khususnya pada Kelurahan Kampung Dalam, Kampung Bandar dan Sago memiliki banyak objek wisata yang letaknya berdekatan. Objekobjek tersebut yaitu Kompleks Masjid Raya dan Makam Marhum Pekan Kota Pekanbaru, Pasar Wisata Pasar Bawah/ Pasar Senapelan Kota Pekanbaru, Rumah Tuan Kadhi, Titik Nol Kota Pekanbaru, Kampung Cina (Vihara Darmaloka). Walaupun memiliki banyak peninggalan sejarah dan budaya, objek-objek wisata yang ada di kawasan ini belum terekspos dengan baik misalnya tapak awal Masjid Nur Alam, gerbang Masjid Raya Senapelan, mimbar Masjid Raya Senapelan, Sumur Tua Masjid Nur Alam, 
Tiang Enam Masjid Raya Pekanbaru, Rumah Tuan Kadi yang berada di Jl. Perdagangan dan Jl. Senapelan, Tugu Titik Nol Pekanbaru dan lainnya. Di samping itu, banyak peninggalan sejarah budaya atau yang diduga cagar budaya di Kampung Bandar Senapelan dan kawasan sekitarnya yang belum terungkap. (m.riaupos.co,2012)

Pada hal kalau ditelusuri, kawasan lama biasanya mempunyai banyak potensi antara lain (Widayati,2000:92) (dalam situs https://kampungbandar.wordpress.com/seja $\mathrm{rah} /$ ): 1. Kehidupan masyarakatnya masih tradisionil baik dari segi spiritualnya maupun kulturalnya; 2. Masyarakat setempat biasanya mempunyai mata pencaharian berupa kerajinan tangan sesuai dengan daerahnya masing-masing; 3. Mempunyai kesenian rakyat; 4. Mempunyai lahan atau bangunan yang spesifik yang dapat dijadikan objek wisata; dan 5. Mempunyai situs peninggalan masa lalu yang berkaitan dengan sejarah.

Kecamatan Senapelan merupakan kecamatan tertua di Pekanbaru dengan luas wilayah $6,65 \mathrm{Km}^{2}$ dan memiliki 6 kelurahan yaitu Kelurahan Kampung Bandar, Kelurahan Kampung Baru, Kelurahan Kampung Dalam, Kelurahan Padang Bulan, Kelurahan Padang Terubuk, dan Kelurahan Sago. Dengan jumlah penduduk 179.172 jiwa pada tahun 2013. Kecamatan ini memiliki batas wilayah yaitu sebelah Barat dengan Kecamatan Payung Sekaki, sebelah Timur dengan Kecamatan Lima Puluh atau Pekanbaru Kota, sebelah Selatan dengan Kecamatan Sukajadi atau Payung Sekaki, dan di sebelah Utara dengan Kecamatan Rumbai atau Rumbai Pesisir.

Dikarenakan merupakan cikal bakal Kota Pekanbaru, kawasan Kecamatan Senapelan yang memiliki beberapa situs sejarah, budaya dan religi, serta pasar yang telah dicanangkan oleh pemerintah Kota Pekanbaru sebagai pasar wisata. Selain itu, Ayat Cahyadi yang merupakan Wakil Walikota Pekanbaru mengatakan bahwa Kelurahan Kampung Bandar akan dicanangkan sebagai salah satu desa wisata di Pekanbaru (seputarriau.com).

Selain objek wisata, di Kecamatan Senapelan juga banyak terdapat event atau atraksi wisata diantaranya Festival Lampu Colok, Festival Bandar Senapelan, Atraksi Barongsai, Festival Lampion, Petasan dan Perayaan Kembang Api di Kampung Cina (Chinatown) dan Petang Megang.

Inskeep (1991:38-39) menyatakan bahwa komponen-komponen dalam pembangunan destinasi wisata terdiri atas "Tourist attraction and activities (objek wisata dam kegiatan wisata), Accommodation (akomodasi), Other tourists facilities and services (fasilitas wisatawan lainnya dan jasa), Transportation facilities and services (fasilitas transportasi dan jasa), Other infrastructure (infrastruktur lainnya), and Instutional elements (elemen institusi)".

Hal ini senada dengan pendapat (Yoeti,1997) pengembangan pariwisata perlu memperhatikan beberapa aspek yakni; Wisatawan, harus diketahui karakteristik dari wisatawan; Transportasi; Atraksi/ Obyek Wisata, apakah memenuhi tiga syarat seperti apa yang dapat dilihat, apa yang dapat dilakukan, apa yang dapat dibeli; Fasilitas Pelayanan, fasilitas apa yang tersedia, aksesibiltas, bagaimana akomodasi yang ada, restaurant, pelayanan umum seperti bank, telpon, kantor pos.

Belum adanya pengelolaan yang baik, banyak obyek-obyek wisata yang seharusnya dapat dikembangkan menjadi terabaikan dan tidak terpelihara. Aspek pendukung pariwisata seperti adanya fasilitas penunjang pariwisata sangat mendukung keberhasilan pariwisata karena memberikan kemudahan pelayanan bagi wisatawan dalam menikmati perjalanan. Di Kecamatan Senapelan masih banyak ditemui jalan yang berlubang, diperlukan kepedulian masyarakat untuk menjaga kebersihan dengan tidak membuang sampah sembarangan sehingga mengakibatkan 
drainase lingkungan yang rusak atau tersumbat, dan dibeberapa tempat yang dekat dengan Sungai Siak apabila air pasang menjadi becek sehingga kurang nyaman apabila dilalui oleh orang atau wisatawan. Apabila melihat pada kawasan Kecamatan Senapelan ini masih belum didukung oleh aksesibilitas yang baik misalkan jalan menuju kawasan wisata terdapat jalan yang rusak, alat transportasi menuju obyek wisata belum terintegrasi dengan baik.

Pada gambar (a) tampak salah satu kondisi parit/ selokan yang terdapat di Jalan Senapelan di depan Polres Senapelan yang letaknya tidak jauh dari Pasar Bawah. Hampir semua kondisi parit yang ada di Kecamatan ini tidak berfungsi lagi dikarenakan sampah dan pasir yang memenuhinya. Pada gambar (b) tampak trotoar yang digunakan sebagai lahan parkir dan meja yang digunakan pedagang untuk berjualan. Gambar (c) memperlihatkan gambar kondisi jalan di Kecamatan ini yang berlubang dan gambar (d) yaitu gambaran kondisi tepian sungai Siak yang airnya acapkali digunakan oleh masyarakat sekitar untuk aktifitas sehari-hari misalnya untuk MCK.

Sedangkan menurut Spillane (1994: 63), suatu lokasi yang dijadikan obyek wisata (destinasi) harus memiliki lima unsur penting agar wisatawan merasa puas dalam menikmati perjalanannya, yaitu atraksi, fasilitas, infrastruktur, transportasi dan keramahtamahan.

Selain itu berdasarkan hasil observasi dan studi-studi terdahulu diketahui bahwa sebaran lokasi kawasan permukiman kumuh di Kota Pekanbaru umumnya berada di sepanjang tepi Sungai Siak dan Sungai Sago, yang meliputi Kelurahan Meranti Pandak, Kecamatan Rumbai Pesisir, Kelurahan Limbungan Kecamatan Rumbai Pesisir, Kelurahan Pesisir Kecamatan Lima Puluh, Kelurahan Kampung Dalam Kecamatan Senapelan, Kelurahan Kampung Bandar Kecamatan Senapelan, Kelurahan Kampung Baru Kecamatan Senapelan, Kelurahan Tampan
Kecamatan Payung Sekaki, dan Kelurahan eks-Teleju di Kelurahan Rejosari. (Pusat Kajian Strategis Kementerian Pekerjaan Umum: 2011)

Adanya perbedaan antara obyek wisata yang satu dengan wisata lain seperti wisata lainnya yang sudah dikembangkan baik oleh pemerintah maupun masyarakat setempat, hal ini menunjukkan perlu adanya pengembangan secara berkelanjutan, terlihat dari banyaknya kunjungan wisatawan yang lebih banyak dan terfokus pada wisata lain seperti Pasar Bawah sebagai Pasar Wisata dan Masjid Raya Pekanbaru sebagai cagar budaya dan sejarah sesuai keputusan Menteri Kebudayaan dan Pariwisata Nomor. KM.13/13.007/MKP/2004, tentang penetapan Istana Siak dan (sejumlah situs lainnya) termasuk Masjid Raya Pekanbaru, yang berlokasi di-Pekanbaru merupakan benda cagar budaya, situs, atau kawasan yang dilindungi UU RI No.5/2004. Yang diperkuat pula dengan adanya Monumenten Ordonnantie Nomor 21/1934 (Staatsblad 515) dan UU No 5 tahun 1992 atau UU No 11 Tahun 2010 tentang benda cagar budaya pada bab III.

Oleh Karena itu diperlukan suatu upaya untuk meminimalisir permasalahan-permasalahan yang menyebabkan obyek wisata yang ada di Kecamatan Senapelan ini kurang berkembang. Upaya tersebut dapat ditempuh dengan membentuk kawasan wisata yang terpadu, terkoordinasi dan memiliki keterkaitan yang kuat sehingga pengembangan Kecamatan Senapelan menjadi kawasan wisata dapat lebih terarah yang pada akhirnya memberikan hasil yang optimal bagi pertumbuhan ekonominya.

Dalam pariwisata spasial seharusnya berisikan konsep pengalaman perjalanan (Travel Experience) dan layanan hospitality (Hospitality Service) dimana dalam produk pariwisata terdapat suatu interaksi antara produk wisata, wisatawan dan masyarakat. Dimana 
produk wisata menyajikan atraksi wisatanya, fasilitas pendukung, serta pelayanan masyarakat terhadap wisatawan. Sehingga apabila hal tersebut saling berinteraksi hasil akhirnya wisatawan yang melakukan perjalanan wisata akan mendapatkan sesuatu sebagai bentuk pengalaman yang berkesan (Suharso:2009).

Pengembangan pariwisata diarahkan pada peningkatan pariwisata menjadi sektor andalan yang mampu mengalakkan kegiatan ekonomi, termasuk sektor-sektor lainnya yang terkait sehingga lapangan kerja, pendapatan masyarakat, pendapatan daerah, pendapatan negara serta penerimaan devisa meningkat melalui pengembangan dan pendayagunaan potensi kepariwisataan nasional (Yoeti:2008). Terwujudnya Kecamatan Senapelan menjadi kawasan wisata akan dapat mewujudkan interaksi antar kawasan, percepatan ekonomi yaitu dengan menciptakan lapangan kerja dan berusaha dimana pertumbuhan ekonomi ditandai dengan peningkatan perdagangan dan jasa, sehingga perbaikan ekonomi masyarakat kawasan wisata di Kecamatan Senapelan dapat diraih yang pada nantinya kemajuan wilayah dapat terwujud.

Tata ruang sendiri pada dasarnya merupakan perwujudan dari kegiatan sosial-ekonomi masyarakat dengan adanya dinamika dan perubahan (Peter Hall:1981). Pengembangan daya tarik wisata menitikberatkan pada penataan dan pengembangan infrastruktur dasar, diversifikasi aktivitas, dan paket wisata serta fasilitas sanitasi yang mengacu pada ketentuan lingkungan dan berkelanjutan. (Suharso:2009). Belum adanya pengembangan kawasan Kecamatan Senapelan menjadi kawasan wisata mengakibatkan belum terwujudnya kesatuan antar obyek wisata di kawasan Kecamatan Senapelan, sehingga antar obyek wisata yang satu dengan obyek wisata yang lain tidak dapat memberi kontribusi sesuai dengan peruntukannya masing-masing. Agar tujuan menjadikan Kecamatan Senapelan menjadi kawasan wisata tercapai maka perlu adanya satu pemahaman antara pemegang kepentingan, bagaimana menjadikan daerah ini menjadi kawasan wisata.

Objek wisata yang ada di daerah Kecamatan Senapelan memiliki kriteria yang dapat dijadikan destinasi baru di Kota Pekanbaru, karena memiliki objek yang unik ditambah dengan atraksi wisata yang rutin dilaksanakan, misalnya Festival Lampu Colok yang rutin dilaksanakan setiap bulan Ramadhan, Festival Bandar Senapelan yang baru-baru ini dilaksanakan, Atraksi Barongsai yang disusul dengan Festival Lampion dan Kembang Api di Kampung Cina sebagai peringatan Hari Raya Imlek yang disusul dengan Cap Go Meh oleh masyarakat etnis Tionghoa yang bertempat tinggal di Pekanbaru, Mandi Balimau atau Petang Megang di tepian Sungai Siak disusul dengan lomba menangkap itik yang dilaksanakan untuk menyambut bulan suci Ramadhan. Oleh karena itu penelitian ini perlu dilakukan untuk mengetahui "Daya Tarik Wisata Apa Saja yang ada di Kecamatan Senapelan Kota Pekanbaru”

Menurut Undang-undang Republik Indonesia No.10 tahun 2009 pasal 1, "Daya tarik wisata adalah segala sesuatu yang memiliki keunikan, keindahan, dan nilai yang berupa keanekaragaman kekayaan alam, budaya dan hasil buatan manusia yang menjadi sasaran atau tujuan kunjungan wisatawan".

Destinasi pariwisata yang memiliki tingkat daya tarik yang tinggi akan mampu bersaing karena daya tarik menjadi faktor inti kegiatan wisata. Daya tarik wisata menjadi faktor penyebab utama seorang wisatawan mengunjungi suatu daerah tujuan wisata, dimana wisatawan melihat pemandangan dan melakukan kegiatan wisata. "Atttactions are the primary elements of destination appeal. They are the key motivators for visitation to a destination" Crouch and Ritchie,1999 (dalam Vengsayi,2003:639).

Tempat yang memiliki nilai spiritual, unik, dan tempat-tempat 
bernostalgia, dapat menjadi daya tarik kelompok wisatawan tertentu karena adanya motivasi yang berkaitan erat dengan perjalanannya. Asosiasi terhadap tempattempat yang mengingatkan pada masa-masa yang lampau baik dirasakan secara langsung maupun hanya merupakan cerita masa lalu dari orang tua juga dapat menjadi daya tarik wisata.

Kušen, 2002 (dalam Kresic and Prebezac, 2011:499) mengidentifikasikan "tourism attractions as tourism resources which could attract, or are already attracting tourists to visit particular tourism destination". Atraksi wisata merupakan sumber daya pariwisata yang mampu menarik atau sedang menarik wisatawan untuk mengunjungi destinasi pariwisata tertentu.

Leask,2010 (dalam Kresic and Prebezac,2011:499), mekankan pentingnya daya tarik wisata dengan mengatakan pentingnya daya tarik wisata dengan mengatakan bahwa daya tarik wisata memainkan peran penting dalam keberhasilan destinasi pariwisata, "tourism attractions play a crucial role in the success of a tourism destination, where the act as key motivators for visits and as resources for local communities".

Fluker,2004 (dalam Pitana,2009:126) mendefinisikan destinasi sebagai suatu tempat yang dikunjungi dalam waktu yang signifikan selama perjalanan seseorang dibandingkan tempat lainnya yang dilalui selama perjalanan, "A significant place visited on a trip, with some from of actual or perceived boundary. The basic geographic unit fo the production of tourism statistics".

Destinasi menurut New Shorter Oxford Dictionary (dalam Vengesayi,2003:638) adalah "The place to wich person or thing is going, the intended and of a journey". Destinasi diartikan sebagai tempat kemana orang dan benda menuju sebagai tujuan akhir dari perjalanan. Destinasi adalah tempat yang menawarkan perpaduan produk wisata dan layanan yang dinikmati di destinasi.

Unsur pokok yang harus mendapat perhatian guna menunjang pengembangan pariwisata di daerah tujuan wisata yang menyangkut perencanaan, pelaksanaan pembangunan dan pengembangannya meliputi 5 unsur: Objek dan daya tarik wisata, Prasarana wisata, Sarana wisata, Inrastruktur, Masyarakat/lingkungan.

Daya tarik wisata yang juga disebut objek wisata merupakan potensi yang menjadi pendorong kehadiran wisatawan ke suatu daerah tujuan wisata. Pengusahaan objek dan daya tarik wisata di kelompokkan kedalam : Pengusahaan objek dan daya tarik wisata alam, Pengusahaan objek dan daya tarik wisata budaya, Pengusahaan objek dan daya tarik wisata minat khusus.

Dalam kedudukannya yang sangat menentukan itu maka daya tarik wisata harus dirancang dan dibangun/ dikelola secara profesional sehingga dapat menarik wisatawan untuk datang untuk datang. Membangun suatu objek wisata harus dirancang sedemikian rupa berdasarkan kriteria tertentu. Umumnya daya tarik suatu objek wisata berdasar pada: Adanya sumber daya yang dapat menimbulkan rasa senang, indah, nyaman dan bersih. Adanya aksesibilitas yang tinggi untuk dapat mengunjunginya. Adanya ciri khusus / spesifikasi yang bersifat langka. Adanya sarana/ prasarana penunjang untuk melayani para wisatawan yang hadir. Objek wisata alam mempunyai daya tarik tinggi karena keindahan alam pegunungan, sungai, pantai, pasir, hutan, dan sebagainya. Objek wisata budaya mempunyai daya tarik tinggi karena memiliki nilai khusus dalam bentuk atraksi kesenian upacara-upacara adat, nilai luhur yang terkandung dalam suatu objek buah karya manusia pada masa lampau.

\section{METODE}

Penelitian ini dilakukan menggunakan analisa deskriptif untuk menyusun dan mengidentifikasikan. Lokasi penelitian ini adalah Kecamatan Senapelan khususnya Kelurahan Kampung Bandar, Kelurahan Kampung Dalam dan Kelurahan Sago, Kota Pekanbaru. Jenis data yang digunakan dalam penelitian ini adalah data kualitatif. Data kualitatif, yaitu data yang 
dinyatakan dalam bentuk keteranganketerangan dan uraian-uraian baik dari berbagai pihak yang berkompeten, wisatawan yang digunakan sebagai informan dalam penelitian ini dan data lainnya.

Data yang diperoleh akan diolah dan di analisis secara deskriptif. Data yang dideskripsikan adalah data yang diperoleh dari hasil pengumpulan data dengan pengamatan, pengukuran, wawancara dan studi kepustakaan yang ditranskripsikan dalam bentuk tulisan. Analisis data dilakukan setelah selesai pengumpulan data di lapangan. Analisis ini akaan menjawab pertanyaan yang ada pada rumusan masalah.

\section{HASIL}

Kecamatan Senapelan memiliki objek wisata yang beberapa diantaranya merupakan warisan budaya dan sejarah Kota Pekanbaru yaitu Masjid Raya dan Kompleks Makam Marhum, Pasar Wisata Pasar Bawah, Rumah Tuan Kadhi, Vihara, Rumah Songket. Selain objek-objek wisata tersebut, ada beberapa peninggalan sejarah yang masi asli dan dapat dilihat di kecamatan ini, yaitu Batu titik nol Kota Pekanbaru, Kitab Dalailama, Sisa peninggalan dari Masjid Raya yaitu Mimbar, Sumer tua, dan Tiang enam, juga Batu Peringatan Pengibaran Bendera Merah Putih Pertama di Kota Pekanbaru.

\section{PEMBAHASAN}

\section{Masjid Raya dan Makam Marhum Pekan Kota Pekanbaru}

Masjid Raya Pekanbaru dibangun pada abad ke 18 tepat 1762 sehingga merupakan mesjid tertua di Pekanbaru dan masuk kedalam salah satu situs cagar budaya. Mesjid yang berlokasi di Jalan Senapelan Kecamatan Senapelan ini merupakan bukti Kerajaan Siak Sri Indrapura pernah bertahta di Pekanbaru (Senapelan) yaitu di masa Sultan Abdul Jalil Alamuddin Syah sebagai Sultan Siak ke-4 dan diteruskan pada masa Sultan Muhammad Ali Abdul Jalil Muazzam Syah sebagai Sultan Siak ke-5, dan sejarahnya berkaitan langsung dengan sejarah makam marhum, dan pasar wisata pasar bawah juga asal muasal berdirinya Kota Pekanbaru.

Sejarah berdirinya Mesjid Raya Pekanbaru dikisahkan ketika di masa kekuasaan Sultan Abdul Jalil Alamuddin Syah memindahkan dan menjadikan Senapelan (sekarang Pekanbaru) sebagai Pusat Kerajaan Siak. Sudah menjadi adat Raja Melayu saat itu, pemindahan pusat kerajaan harus diikuti dengan pembangunan "Istana Raja", "Balai Kerapatan Adat", dan "Mesjid". Ketiga unsur tersebut wajib dibangun sebagai representasi dari unsur pemerintahan, adat dan ulama (agama) yang biasa disebut "Tali Berpilin Tiga" atau "Tungku Tiga Sejarangan".

Pada penghujung tahun 1762, dilakukan upacara "menaiki" ketiga bangunan tersebut. Bangunan istana diberi nama "Istana Bukit" balai kerapatan adat disebut "Balai Payung Sekaki" dan mesjid diberi nama "Mesjid Alam" (yang mengikut kepada nama kecil sultan Alamuddin yaitu Raja Alam). Pada tahun 1766, Sultan Alamuddin Syah meninggal dan diberi gelar Marhum Bukit. Sultan Alamuddin Syah digantikan oleh puteranya Tengku Muhammad Ali yang bergelar Sultan Muhammad Ali Abdul Jalil Muazzam Syah. Pada masa pemerintahannya (17661779), Senapelan berkembang pesat dengan aktivitas perdagangannya. Para pedagang datang dari segala penjuru. Maka untuk menampung arus perdagangan tersebut, dibuatlah sebuah "pekan" atau pasar yang baru, pekan yang baru inilah kemudian menjadi nama "Pekanbaru" sekarang ini.

Perkembangan yang begitu pesat menyebabkan Mesjid Alam tidak lagi cukup menampung para jemaah yang beribadah maupun yang menuntut ilmu agama di sana. Apalagi Sayid Osman, seorang ulama, menggunakan mesjid tersebut sebagai pusat dakwah menyebarkan Agama Islam. Atas dasar musyawarah Sultan Muhammad Ali, Sayid Osman, Datuk Empat Suku beserta para pembesar lainnya, disepakati untuk memperbesar mesjid tersebut.

Pada tahun 1775, pekerjaan 
membesarkan bangunan mesjid dilakukan. Menurut sumber lokal, bangunan masjid yang diperbaharui tersebut, keempat "Tiang Seri" disediakan oleh Datuk Empat Suku, "Tiang Tua" disediakan oleh Sayid Osman, "Kubah Mesjid" disediakan oleh Sultan Muhammad Ali, sedangkan pengerjaannya dilakukan oleh seluruh rakyat. Cara ini menunjukkan persebatian/ kesatuan antara Pemerintah, Ulama, Adat dan masyarakat. Acuan ini kemudian dikekalkan di Kerajaan Siak, yang mengandung maksud tertentu pula:

1. Sultan : Pucuk pemerintahan pemegang daulat

2. Datuk Empat Suku

Tiang pemerintahan pemegang adat

3. Ulama : Tiang agama pemegang hukum syarak

4. Rakyat : Darah daging kerajaan pemegang Soko Pusaka,

petuah dan amanah

Diperbesarnya mesjid ini diikuti dengan penggantian nama mesjid menjadi Mesjid Nur Alam yang berarti memberikan cahaya ke alam sekitarnya dan memberikan penerangan bagi hati umat manusia.

Pada tahun 1779, Sultan Muhammad Ali diganti oleh iparnya Sultan Ismail (17791781) yang kemudian setelah mangkat digantikan oleh Sultan Yahya (1781-1784). Sultan Yahya diganti oleh putera Sayid Osman yaitu Tengku Udo Sayid Ali bergelar Assyaidissyarif Ali Abdul Jalil Syaifuddin (1784-1810). Pada masa pemerintahannya, pusat Kerajaan Siak dipindahkan ke Mempura Kecil (Kota Siak sekarang). Masa itu juga, Mesjid Nur Alam diberi selasar (teras) yang dipergunakan untuk tempat peziarah duduk, sekaligus tempat pemberian/pelafasan gelar. Konon sejak itu, banyaklah mesjid dibangun menggunakan selsar di sekeliling bangunan, sekurangkurangnya di salah satu sisi bangunan.

Pada masa pemerintahan Sultan Ismail II yang bergelar Sultan Assyadisyarif Ismail Abdul Jalil Syaifuddin (1827-1864), Mesjid Nur Alam diperbaiki lagi dan memperbesar selasarnya. Sultan Ismail II mangkat pada tahun 1864 dan digantikan puteranya Tengku Sayid Kasim (Sultan Syarif Kasim Awal). Pada masa ini tidak ada perubahan yang mendasar pada bangunan mesjid. Perubahan baru terjadi ketika Tengku Putera Sayid Hasyil memegang tampuk pemerintahan (18891908). Pada masa itu, Mesjid Nur Alam dipindahkan 40 langkah dari posisi semula ke arah matahari hidup/terbit (timur). Dengan dipindahkannya posisi mesjid ini, maka mesjid ini terkenal dengan Mesjid Sultan yang berarti dipindahkan oleh Sultan. Karena bangunannya lebih luas, maka disebut juga Mesjid Besar yang kadang juga disebut Mesjid Raya.

Sultan Sayid (Said) Hasyim mangkat pada tahun 1908 dan digantikan puteranya Tengku Said Kasim yang bergelar Sultan Assyaidissyarif Kasim Abdul Jalil Syaifuddin yang biasa disebut Sultan Syarif Kasim II. Sultan memerintah sampai kerajaan Siak berakhir di tahun 1946 ketika bergabung dengan Negara Kesatuan Republik Indonesia (NKRI). Pada tahun 1935, Sultan Syarif Kasim II memutuskan untuk membangun mesjid lebih besar dengan bahan semen dan batu yang letaknya berdekatan dengan mesjid lama yang sudah ada, dengan dasar pertimbangan hakikatnya masih menyatu dengan mesjid lama. Maka dalam tahun itu juga dimulailah pembangunan mesjid yang dimaksud, yang namanya tetap menjadi Mesjid Raya. Pemilihan lokasi yang berdekatan ini dengan pertimbangan sebagi berikut :

1. Mesjid baru hakikatnya masih menyatu dengan mesjid lama

2. Mesjid baru lokasinya berdekatan dengan makam-makam nenek moyang beliau.

3. Mesjid baru dibangun supaya lebih tahan dan lebih besar.

4. Mesjid baru ini dibangun sebagai tanda ingat beliau kepada nenek moyangnya yang telah berjasa mengembangkan Islam di Kerajaan Siak dan sekitarnya.

Berdasarkan Monumenten

Ordonnantie Nomor 21/1934 (Staatsblad 
515), Masjid tertua di Riau ini masuk kategori benda cagar budaya. Hal itu diperkuat dengan UU No 5 tahun 1992 atau UU No 11 Tahun 2010 tentang benda cagar budaya pada bab III. Selain itu diperkuat pula dengan keputusan Menteri Kebudayaan dan Pariwisata

Nomor.

KM.13/13.007/MKP/2004, tentang penetapan Istana Siak dan sejumlah situs lainnya termasuk Masjid Raya Pekanbaru sebagai situs benda cagar budaya dan kawasan yang dilindungi.

Menurut Pak Dadang, salah satu guide yang berada di lingkungan masjid yang sempat diwawancarai oleh penulis menyatakan bahwa, renovasi Masjid Raya Pekanbaru kali ini dilakukan oleh Badan Revitalisasi Kawasan Masjid Raya Pekanbaru yang biaya revitalisasinya ditangung oleh Pemprov Riau melalui dana APBD Riau. Mengingat besar dan luas masjid saat ini, diperkirakan memakan biaya miliyaran rupiah yang digunakan selain untuk memperluas area masjid yaitu untuk pembebasan lahan juga dikarenakan akan membangun sarana islamic centre, museum, perpustakaan, pusat pertokoan, dan pelabuhan.

"Pernah terjadi silang pendapat pada masa walikota saat itu yaitu Pak Herman Abdulah yang juga masuk menjabat Ketua Dewan Pengurus Masjid antara arkeolog, badan revitalisasi masjid, Lembaga Adat Melayu, sejarawan dan beberapa kelompok ulama mengenai revitalisasi masjid. Perdebatan tersebut terjadi dikarenakan wacana membongkar tiang-tiang sisa masjid sejarah dengan alasan pembongkaran karena memutus shaf. Kepala Badan Revitalisasi Kawasan Masjid Raya Pekanbaru mengatakan bahwa masalah revitalisasi masjid sudah melalui tahap penelitian cukup lama yaitu sekitar satu tahun lebih dan telah menyiapkan konsep itu sejak 2007, dan mensosialisasikan kepada tokoh-tokoh Riau melalui wadah lembaga adat, pemuka masjid, pemerintah kota, dan DPRD Provinsi.

Kenyataannya, setelah melihat proses pemugaran yang dilakukan Badan Revitalisasi Masjid Raya Pekanbaru,
Lembaga Adat Melayu (LAM) menyatakan keterkejutannya, karena bangunan utama ternyata telah dihancurkan. Selain LAM, komunitas melayu termasuk sanak famili keturanan kerajaan Siak Sri Indrapura, Sultan Syarif Kasim II merasa "kecolongan" dengan kehadiran proyek revitalisasi ini. Setelah dikonfirmasi ulang, pihak dari Badan Revitalisasi mengatakan bahwa Masjid Raya Pekanbaru belum ditetapkan sebagai cagar budaya. Padahal masjid yang berdiri sejak tahun 1762 ini, saat ini usianya telah mencapai 253 tahun.

Di sebelah kiri pojok bangunan masjid terdapat sumur tua yang posisinya sejajar dengan pintu masuk utamanya yang airnya tidak pernah habis walau di musim kemarau. Biasanya air disumur ini digunakan oleh masyarakat sekitar untuk tempat mengambil air wudlu dan juga tempat mandi, tetapi sejak sumur ini dibentengi oleh tembok sehingga tidak bisa lagi dipakai masyarakat. Untuk melihatnya harus lapor ke penjaga masjid setempat. Padahal sumur tua-itu sangat dikenal sampai ke Malaysia - Singapura karena dipercaya bertuah dan dapat menyembuhkan penyakit sehingga mereka menjadikan air sumur tersebut sebagai oleholeh. Dulunya sumur yang terletak dipojok kiri masjid ini merupakan tempat mandi dan untuk mengambil air wudhu keluarga kesultanan. Sultan dulunya memiliki surau (masjid dalam ukuran kecil) yang letaknya tidak jauh dari banguan Masjid Raya saat ini. Jarak surau dengan sumur itu sekitar 70 meter. Sumur dianggap ajaib karena hanya hitungan 7 meter sudah keluar airnya. Dulunya sumur itu berdiameter hanya 100 cm meter". tutur beliau.

Sedangkan untuk puncak keraimaian pengunjung pada masjid bersejarah ini yaitu pada Bulan Ramadhan, sedangkan pada hari-hari biasa tidak terlalu ramai.

Dikarenakan revitalisasi besarbesaran pada situs Masjid Raya ini, hanya tersisa beberapa situs yang masih asli dan masi dapat dilihat keberadaannya, yaitu tiang 6 Masjid Raya, Sumur, dan Mimbar 
Masjid Raya. Selain itu dikarenakan pelebaran areal masjid, rumah-rumah lama yang berada di depan komplek masjid di bongkar untuk dijadikan lahan parkiran masjid.

\section{Makam Marhum Pekan dan Bukit}

Komplek makam Pendiri Kota Pekanbaru Marhum Pekan merupakan Situs Cagar Budaya yang terdapat di Kota Pekanbaru, situs ini terletak di kelurahan kampung Bandar kecamatan Senapelan. Komplek makam ini merupakan pemakaman keluarga Kerajaan Siak yang pernah memerintah di Kota Pekanbaru. Dulu masyarakat yang bermukim disekitar komplek makam ini lebih mengenal makam ini dengan sebutan perkuburan Mesjid Raya atau Kuburan Raja. Pada tahun 2004 makam ini dirubah namanya menjadi Komplek Makam Marhum Pekan karena ada Makam Marhum Pekan pendiri Kota Pekanbaru.

Dalam komplek makam ini terdapat situs peninggalan sejarah yang sering dikunjungi oleh wisatawan sebagai objek wisata sejarah dan religi yang bernilai tinggi, seperti:

Makam Sultan Abdul Jalil Alamuddin Syah (Marhum Bukit)

Sultan Abdul Jalil Alamuddin Syah atau Sultan Alam, atau Tengku Alam atau Raja Alam adalah Sultak ke 4 Kerajaan Siak. Beliau adalah Sultan yang memindahkan Kerajaan Siak dari Mempura ke Bukit Senapelan (Kampung Bukit) pada tahun 1762.

Makam Sultan Muhammad Ali Abdul Jalil Muazzam Syah (Marhum Pekan)

Sultan Muhammad Ali Abdul Jalil Muazzam Syah adalah Sultan ke 5 Kerajaan Siak yang juga pendiri kota Pekanbaru yang telah dirintis oleh Ayah beliau sehingga menjadi suatu pekan (pasar) yang besar dan ramai sebagai cikal bakal berdirinya Kota Pekanbaru saat ini
Makam Sayid Osman Sahabuddin (Marhum Barat)

Sayid Osman Sahabuddin bin Abdurrahman Sahabuddin adalah menantu dari Raja Alam sekaligus Panglima Perang kerajaan Siak dan Ulama Kerajaan pada masa itu. Said Osman menikah dengan Tengku Embong Badariah. Dari keturunan beliaulah para Sultan Siak dan Raja Pelalawan mewarisi garis keturunan Arab dari Saydina Ali dan fatimah yang bernasabkan Rasulullah SAW (Bani Hasimiyyah)

Makam Sultanah Khodijah atau Daeng Tijah (Istri Marhum Bukit)

Sultana Khodijah atau Daeng Tijah binti Daeng Pirani adalah istri dari Sultan Alamuddin Syah. Beliau merupakan Keturunan Opu-Opu Bugis yang berkuasa di Kerajaan Riau Lingga. Selain sebagai istri seorang Sultan, beliau juga aktif dalam Kerajaan Siak sebagai pengganti Sultan apabila Sultan tidak ada dipemerintahan kerajaan sehingga beliau boleh memakai gelar Sultanah dan dalam Kerajaan Siak hanya ada dua permaisuri yang memakai Gelar Sultanah.

Makam Tengku Embong Badariah (Istri Marhum Barat)

Tengku Embong Badariah adalah istri dari Sayid Osman Sahabuddin Putri dari Sultan Alam (Marhum Bukit).

Makam Sayid Zen Al Jufri/ Tengku Pangeran Kesuma Dilaga

Makam Sayid Zen Al Jufri bergelar Tengku Pangeran Kesuma Dilaga adalah Cucu dari Sultan Alam dari anak beliau yang bernama Tengku Hawi/Hawa yang menikah dengan Sayid Sech AL Jufri . Pangeran Kesuma Dilaga merupakan Panglima Perang Kerajaan Siak pada masa Sultan Siak ke 7 dan 8.

Selain makam-makam diatas juga terdapat makam-makam keluarga raja yang terletak di sekitar komplek makam marhum. 
Makam Keluarga Raja yang Terdapat Di Komplek Makam Marhum

"Pengelolaan Masjid Raya dan komplek Makam Marhum dipegang oleh pengurus masjid yaitu Pak H. Herman. MAT sebagai ketua umum, Pak Pangadilan Nasution sebagai wakil ketua, saya, Ahmad, dan Tohiran yang bertugas selain menjadi pengurus masjid juga sebagai guide di lingkungan kompleks Masjid Raya dan Makam Marhum dibantu dengan tokoh-tokoh masyarakat sekitar", tutur Pak Dadang.

Aktifitas masjid dilangsungkan setiap harinya mulai dari subuh hingga malam hari untuk kegiatan ibadah sholat fardhu dan setiap hari jumat untuk kegiatan sholat jumat. Selain sebagai satu sarana peribadatan umat islam di Kecamatan Senapelan, pihak pengurus masjid rutin mengadakan kegiatankegiatan seperti Menyelenggarakan Dakwah Islam/Tabliq Akbar dan Menyelenggarakan Kegiatan Hari Besar Islam.

Pada hari biasa, umumnya makam marhun dikunjungi oleh lebih kurang 100150 orang setiap harinya, apalagi pada harihari tertentu misalnya pada beberapa hari sebelum dan pada akhir bulan puasa. Umumnya untuk melakukan ziarah kubur. Bahkan pelancong dari Malaysia dan beberapa negara tetangga juga sempat datang untuk ziarah dan berdoa. Makam ini merupakan bangunan ke empat yang didirikan oleh Sultan Alam setelah masjid, balai kerapatan adat dan istana.

\section{Pasar Wisata Pasar Bawah/Pasar Senapelan Kota Pekanbaru}

Camat Senepalan mengatakan bahwa "pasar ini merupakan milik Pemerintah Kota Pekanbaru dibawah naungan Dinas Pasar Kota Pekanbaru yang dikelolah oleh pihak ke III yaitu investor. Dahulunya pasar ini hanyalah pasar tradisional biasa dengan bangunan semi permanen dengan kios dan lapaknya yang terbuat dari papan dengan jalan-jalan sempit yang memisahkan kios dan lapak, yang jika turun hujan akan becek dan berlumpur. Akan tetapi sejak dicanangkannya pasar ini menjadi pasar wisata, maka pasar ini menjadi lebih diperhatikan pemerintah Kota Pekanbaru". Hal yang sama dibenarkan oleh ibu Epi dari Dinas Pariwisata Kota Pekanbaru bahwa "Pasar Bawah telah dinyatakan didalam RPMJ Kota Pekanbaru Tahun 2012-2017 sebagai salah satu dari 13 Kawasan Rekreasi yang berada di Kota Pekanbaru". Berikut adalah gambar Pasar Bawah/ Senapelan Kota Pekanbaru.

"Renofasi yang dilakukan menghasilkan pengaruh positif pada peningkatan jumlah pengunjung yang datang pengunjung sehingga mereka lebih merasa nyaman berkunjung ketempat ini, sehingga berimbas pula pada peningkatan penghasilan pedagang yang berjualan didalam maupun disekitar lokasi Pasar Bawah/ Senapelan. Selain itu, adanya promosi baik itu dari mulut ke mulut maupun dari berbagai media tentang objek wisata ini, membuat pasar bawah lebih dikenal masyarakat dalam maupun luar Kota Pekanbaru maupun manca negara" tutur camat senapelan tersebut.

Didalam lokasi bangunan Pasar Bawah ini dapat menemukan bermacammacam produk yang ditawarkan kepada wisatawan dan masyarakat yang berkunjung, yaitu barang-barang keperluan harian, ikan salai dari berbagai daerah, contohnya ikan salai patin, ikan salai baung, ikan salai asin lomek dan ikan salai asin biang, camilan dari dalam negeri dan luar negeri, misalnya keripik ubi, keripik pisang, salai pisang, dan lain-lain, produk buatan tangan tradisional, misalnya Songket Riau dan cendramata lainnya, tas impor yang berasal dari luar negeri, Barangbarang eks luar negeri : keramik dari Cina, karpet dari Timur Tengah, tas wanita dari Italia, dan aneka guci dan patung, barangbarang elektronik (second hand), dan lainlain sebagainya.

\section{Songket Melayu Riau, Guci dan Keramik Eks Luar Negeri}

Hal yang menarik lainnya yang ditawarkan oleh pasar ini yaitu suasana transaksi di mana si pembeli dapat melakukan tawar menawar harga pada 
produk yang diinginkan. Struktur bangunan empat lantai ditambah areal parkir dilantai dasar (basement) dan corak arsitekturnya yang merupakan campuran antara gaya Melayu dan Tionghoa, sehingga pengunjung dapat merasakan suasana seolah-olah berada di Chinatown Singapura. Selain itu tersedia fasilitas umum seperti toilet umum, mushola, dan area parkir. Juga tersedia eskalator yang dapat memudahkan pengunjung untuk berpindah dari satu lantai ke lantai lainnya.

"Sayangnya pasar yang telah dicanangkan menjadi pasar wisata ini tidak memiliki lahan parkir kendaraan, sehingga dari jalan masuk sampai dengan jalan keluar pasar ini rawan terjadi kemacetan. Hal itu dikarenakan lahan parkiran jalan ini menggunakan bahu jalan" ujar Pak El Mustian.

Akses ke lokasi tidak terlalu susah, karena masih berada di dalam wilayah Kota Pekanbaru, yaitu di Jalan Ahmad Yani, Kecamatan Senapelan, Kota Pekanbaru. Pengunjung dapat langsung menggunakan kendaraan umum maupun bus ke lokasi Pasar Bawah. Demi kenyamanan pengunjung baik itu masyarakat maupun wisatawan dalam negeri dan luar negeri, pasar ini juga menyediakan kantor keamanan yang terletak di lantai dasar pasar bawah, lahan parkir yang mengelilingi bangunan pasar, ATM Mandiri dan BNI yang terletak di samping pasar. Selain itu juga tersedia pos polisi milik Polri Resort Kota Pekanbaru Pasar Bawah yang letaknya di samping pasar tepatnya di pintu keluar pasar bawah.

"Aktifitas jual beli yang berlangsung di pasar ini terjadi setiap hari mulai dari pagi dampai sore hari menjelang magrib dengan puncak kunjungan pengunjung yaitu pada hari libur dan pada akhir bulan Ramadhan. Umumya pengunjung yang datang merupakan wisatawan yang datang untuk membeli oleh-oleh" ujar camat senapelan.

\section{Pos Polisi yang Berada di Pasar Wisata Pasar Bawah}

Camat Senapelan menjelaskan bahwa dahulunya barang-barang bekas atau selundupan dari luar negeri membanjiri pasar yang terletak di dekat Pelabuhan Sungai Siak ini. Namun seiring berjalannya waktu, pemerintah berangsur-angsur memperketat peraturan. Barang-barang yang dulunya dengan bebas masuk sekarang tidak bisa lagi masuk ke pasar ini. Hal itu tentunya akan berimbas pada berkurangnya jenis barang yang diperjual belikan.

\section{Rumah Masyarakat Tradisional Khas Melayu}

Di pinggiran Sungai Siak, tepatnya di Kelurahan Kampung Bandar sangat mudah dijumpai bangunan rumah tradisional berarsitektur melayu milik masyarakat tempatan. Dikarenakan nilai sejarahnya dan mulai mengertinya masyarakat tempatan mengenai pariwisata, banyak bangunan rumah lama yang dipertahankan keasriannya. Rumah yang dibangun pada tanggal 23 Juli 1928 yang telah dibeli dan direnofasi kembali oleh Pemerintah Kota Pekanbaru Dinas Budaya dan Pariwisata, dan sampai saat ini belum dibuka untuk umum.

\section{Rumah Tradisional Melayu}

"Rumah Tuan Kadi Zakaria yang terletak di Jalan Perdagangan merupakan rumah persinggahan Sultan Syarif Kasim II ketika bertandang ke Pekanbaru. Di rumah itu juga berbagai persoalan dan strategi menata Bandar Senapelan selalu dibahas. Itu rumah kenangan masa lalu Sultan Siak yang kini menempati rumah Tuan Kadi Zakaria di Jalan Senapelan Gang Pinggir bersama istrinya yang juga cucu Tuan Kadi Zakaria. Rumah peninggalan Tuan Kadi Zakaria memang telah dipugar tapi tak mengubah bentuk asli bangunan" ujar Bapak El Mustian, yang merupakan dosen seni budaya di Universitas Negeri Riau (UNRI).

\section{Vihara}

Harmonisasi agama di Kecamatan Senapelan tampak jelas saat mengunjungi kawasan kampung cina (chinatown) atua yang dikenal juga dengan Kampung Tionghoa Melayu yang berlokasi di Jalan Karet/ Dr. Leimena di Kelurahan Sago. Hal 
itu terbukti dari adanya Vihara Darmaloka yang lokasinya tidak jauh dari kawasan Masjid Raya Pekanbaru.

Salah satu pengelola Vihara ini mengatakan bahwa vihara ini di kelola oleh Ikatan Keluarga Tionghoa Pekanbaru dibawah naungan Yayasan Centiya Tri Ratna atau Tri Ratna Buddish Centre Pekanbaru. Vihara ini diresmikan pada tanggal 30 mei 1993 oleh gubernur kepala daerah tingkat I Riau kala itu yaitu bapak Soeripto dan Dirjen Bimas Hindu dan Buddha Departemen Agama Republik Indonesia kala itu yaitu Drs. I Gusti Agung Gde Putra.

"Puncak keramaian pengunjung di vihara ini yaitu pada saat pelaksanaan Hari Raya Imlek dan Cap Go Meh. Di vihara ini disimpan Kitab Dalai Lama, sebuah manuskrip kitab kuno peninggalan Dalai Lama yang berusia lebih dari 100 tahun di perkampungan Tionghoa Melayu, tepatnya di Wihara Tri Ratna Budhis Centre, Jalan Karet Pekanbaru. Kitab yang berisi ajaran Tantrayana setebal 108 lembar ditulis dalam bahasa Sansekerta menggunakan tinta emas di atas kulit kayu. Kitab dari Nepal ini diperkirakan berasal dari masa Dalai Lama Thubten Gyatso yang pernah jadi pemimpin spiritual pada 1879."tuturnya.

Dengan ditemukannya kitab ini, diharapkan dapat menambah literatur sejarah Bandar Senapelan sebagai salah satu kawasan sejarah. Berikut adalah gambar Vihara

\section{Rumah Tenun Songket Senapelan}

Rumah tradisional yang berumur sekitar 127 tahun yang dulunya merupakan saksi bisu sejarah Pekanbaru yang saat ini beralih fungsi menjadi Rumah Tenun Songket. Dikatakan oleh Drs. H. A. Tanwir Ayang, Msi yang merupakan Tokoh Budayawan Pekanbaru yang termuat didalam baliho yang terpampang di depan pintu masuk rumah tua ini bahwa rumah yang diperkirakan dibangun pada tahun 1887 dan ditempati oleh $\mathrm{H}$. Yahya, seorang touke (juragan) getah karet ternama pada masa itu bersama istrinya Zainab serta anak-anaknya yang merupakan salah satu Pejuang Perintis
Kemerdekaan Indonesia, $\mathrm{Hj}$. Razmah Yahya, Kamsiah Yahya, Hj. Ramhan Yahya dan Nurisah Yahya.

Pada awal Pra Kemerdekaan rumah ini pernah dijadikan basis Pejuang Fisabilillah sekaligus menjadi gudang logistik dan dapur umum. Namun karena alasan keamanan maka dipindahkan ke surau Irhash yang terletak di Jalan Senapelan. Selepas Pasca Kemerdekaan tahun 1958 rumah ini dijadikan salah satu Markas sekaligus tempat tinggal Tentara Nasional Indonesia Pusat di Era penumpasan Pemberontakan PRRI di Sumatera Bagian Tengah khususnya Propinsi Riau.

Selain itu, rumah ini juga pernah ditempati oleh KH. Muhammad Sech seorang Imam Besar Masjid Raya Nur Alam/ Mesjid Raya yang juga menjabat sebagai Kadi yang diangkat langsung oleh Raja Siak yaitu Sultan Syarif Qasim, beliau adalah salah seorang menantu dari $\mathrm{H}$. Yahya. Selanjutnya rumah ini ditempati oleh $\mathrm{H}$. Yahya yaitu $\mathrm{Hj}$. Ramnah Yahya yang bersuamikan $H$. Ibrahin beserta keempat anaknya.

"Semasa ditempati oleh keluarga $\mathrm{Hj}$. Ramnah Yahya, rumah ini digunakan untuk aktifitas mangajar ngaji anak-anak, bertenun dan menokat. Beliau juga berprofesi sebagai Mak Andam Pesta Perkawinan Adat. Selanjutnya rumah ini sitempati oleh salah seorang anak $\mathrm{Hj}$. Ramnah Yahya yaitu Yusuf Ibrahim. Karena sudah mempunyai rumah sendiri, kondisi rumah tersebut kosong dan saat ini dipergunakan untuk kegiatan Kelompok Swadaya Masyarakat Tenun Songket Senapelan khususnya ibu-ibu dilingkungan Kampung Bandar yang mendapat pembinaan dari PNPM Mandiri melalui Lembaga Pemberdayaan Masyarakat (LPM)".

"Aktifitas yang berlangsung di rumah tenun ini yaitu mulai dari memintal benang tenun sampai dengan proses pembuatannya menjadi kain songket hingga menjadikannya sebagai sufenir. Pengunjung yang datang biasanya berasal dari orang- 
orang yang memesan tenun songket melayu, hal itu dikarenakan informasi keberadaannya saat ini hanyalah dari mulut kemulut" ujar salah seorang pengrajin tenun songket yang bekerja di Rumah Tenun Songket tersebut.

\section{SIMPULAN}

Daya Tarik dan aktifitas wisata (tourist attractions and activities) $\mathrm{di}$ Kecamatan Senapelan merupakan dayatarik wisata sejarah dan budaya yang lokasi objekobjek wisatanya berdekatan, tapi keberadaannya belum terekspos dengan baik.

Promosi pariwisata pada Kecamatan Senapelan lebih di intensifkan kembali khususnya pada situs cagar budaya dan sisasisa peninggalannya lebih diekspos. Tidak hanya promosi, pada lokasi keberadaan situs tersebut harus dibuatkan petunjuk arah keberadaannya sehingga memudahkan wisatawan untuk mengetahui keberadannya dan lebih dijaga keasriannya.

\section{DAFTAR RUJUKAN}

Katalog BPS: 1102001.1471.07, Kecamatan Senapelan Dalam Angka 2015.

Hall, Peter and Page S.J. 1981. The Geography of Tourism and Recreation: Environment, Place and Space. London: Bbath Press Ltd.

Kresic, Damir, 2001. Index of Deatinination Attractiveness as a Tool for Destination Attractiveness Assessment. Zagreb, Croatia. Institute for Tourism. Vol.59 N04.497-517

Sugiyono, 2008. Metode Penelitian Kuantitatife, Kualitatife, dan $R \& D$. Bandung: ALFABETA.

Suharso, 2009. Perencanaan Objek Wisata dan Kawasan Pariwisata. Program Pascasarjana Universitas Brawijaya Malang.
Smith, Stephen L, 1989. J :The Measurement of Global Tourism: Old Debates, New Consensus, And Continuing Challenges" In Lew, Alan A. C. Michael Hall.

Spillane, James J. 1994. Ekonomi Pariwisata, Sejarah dan Prospeknya. Yogyakarta: Kanisius

Sutopo, HB. 2006, Metode Penelitian Kualitatif, Surakarta: UNS Press.

Vengesayi, Sebastian. 2003. A conceptual Model of Tourism Destination Competitiveness and Attractiveness. ANZMAG. Conference Proceeding Adelaide 1-3 December 2003 